\title{
The Literature of Teacher of Islamic Education at the Senior High School in Bogor City
}

\section{Zulkarnain Yani}

Religious Literature of the Board of Research and Development

Ministry of Religious Affairs, Jakarta, Indonesia

Email: zulkarnainyani@yahoo.com

\begin{abstract}
This paper describes the interest of reading Islamic education teachers at senior high school in the city of Bogor - West Java. This study was conducted in August - September 2016. The focus of the discussion on the urgency of reading religious literature according to Islamic education Teachers at senior high school in Bogor City and a wide selection of literature that the teachers are interested in. The targets are senior high school of Islamic education teachers that have been certified, both civil servant teachers and non-civil servant teachers. The purpose of this research is to know more deeply about reading interest through the urgency of reading religious literature according to Islamic education teachers at senior high school in Bogor City and a wide selection of literature that interest teachers and used in teaching Islamic Religious Education materials in schools. Based on the results of research, overall, interest in reading owned by Islamic education teachers in Bogor city is still very good. As many as $94 \%$ or 34 Islamic education teachers at senior high school who say the importance of reading religious literature is essential. The variety of literature that is preferred by Islamic education teachers at senior high school in Bogor more on the material Aqidah followed by the material fiqh, morals and history of Islamic civilization.
\end{abstract}

Keywords: Literature, Reading Interest, Islamic Education Teachers

"Book is a window of the world". The key to open it, is reading. This phrase clearly describes the benefits of reading to open and broaden one's horizon and knowledge, in order to know more about the unknown world. These activities can be done by anyone such as children, adolescents, adults, and elderly people. Reading culture is the key to the development of a nation. The ability to read and write literacy is a key requirement to build civilization because literacy skills are the key to science (Sulandari, 2016).

Reading is an important key to personal, social, economic and civic life in general (Clark \& Rumbold, 2006, p. 5). Reading is also said to be part of the way to success in life. A good reader will be able to develop his or her point of view, 
experience and thought. Reading is also considered as a necessary skill in the world being led by information technology as it is today (Khairuddin, 2013, p. 160).Particularly in the world of education, reading is one way to gain knowledge from all over the world.

Soedarso said that reading is a complex activity by directing a large number of discrete actions, including the one who has to use the understanding and delusion, to observe and to remember (Kridalaksana, 1984). Reading is one of the most important functions in life. All learning process is based on the ability of reading, therefore the ability of reading in a community will bring the community to the condition of the learning community (learning society). The realization of a learning society will help the achievement of an intelligent nation (educated nation) that has excellent human resources (HR) so as to compete with other nations.

Referring to the data released by the Central Bureau of Statistics in 2012, as many as 91.58 percent of Indonesians aged 10 years and over prefer to watch television. Only about 17.58 percent of the population is like reading books, newspapers or magazines. This indicates that the reading interest of the Indonesian population is very low. In the same year, UNESCO launched an index of reading level of Indonesians which is only 0.001. That means, out of 1,000 residents, there is only one person who wants to read the book seriously (FAS, 2016) By 2015 the National Library conducts research in 12 provinces and 28 districts / cities covering 75 percent of the Indonesian territory, whose result indicates that the reading interest of the community also shows a 25.1 or low category (Munir, 2016). On March 9, 2016, Central Connecticut State University published their research on the world's reading interest rank, in World's Most Literate Nations data, Indonesia ranked 60th out of 61 countries, above the Botswana (Miller, n.d.).

The lack of interest in reading Indonesian society not only happens in the poor and lowly educated, but also occurs among the educated, including teachers. Some teachers feel that it is not necessary to read again because they have finished their college, or because they thinks that the subject is not their fields, or the reading materials are not needed in school. Even if they want to read or learn something, it is only related to the task of teaching or field of study that they received. Some even feel being forced by school demands or have to go to college again to get degree (Trimanto, 2016).

The task and role of teachers from day to day is getting heavier and heavier, along with the development and progress of science and technology. Teachers as a major component in the world of education are required to be able to balance even 
beyond the development of science and technology which is developed in society. Therefore, what is needed is a teacher who has the competence and has a character of cadre who always passionate in carrying out his or her professional duties innovatively (Kunandar, 2007).

By reading the teacher can gain knowledge quickly and easily because he or she can just choose a book to read, open it and start reading word-of-mouth. Therefore reading should be the main activity of teachers (Abdullah, 2016). Semiawan $(2008$, p. 27) said that reading can enrich experience, develop reasoning power, develop creativity, understand yourself and others, and can develop personality. Teachers should be encouraged to love reading so they will always update their insights and knowledge. By reading will be able to develop teachers' critical and creative power. Critical power and creativity are important aspects to create new and meaningful quality learning. On the other hand, by having the additional new knowledge, the teacher will always update the quality of learning.

For the context of reading culture, several studies have shown that teachers can be models or models for their students' reading habits (Cramer \& Blachowichz, 1980; Burgess, Sargent, Smith, Hill, \& Morisson, 2011). Teachers are the instruments in guiding students in reading habits (Huang, Tsai, \& Huang, 2015). Reading teachers, according to McKool and GesPass (2009) research results, will tend to spread the insights and wisdom from the reading to the students, and will be followed by the students.

In this connection, one of the successful learning processes of Islamic education in the classroom is the existence of a significant professional competence of a teacher through reading interest in books or religious literature. Teachers of Islamic education subjects should be able to deliver the rich and comprehensive subject of Islamic education. Must follow the times, update the latest information, science and technology in order to deliver the actual and contextual material to learners. Do not let the Islamic religious education material which is taught is out of date, obsolete, not in accord with the times, and not in accord with the needs of learners (Apandi, 2016).

This is in line with Law No. 14 of 2005 article 10 on teacher competence and Permendiknas Number 16 Year 2007 on Academic Qualification and Teacher Competency Standards, it is mentioned that a subject teacher should use instructional media and learning resources relevant to the characteristics of learners and subjects Which is taught to achieve the learning objectives as a whole. Related to the source of learning, the teacher of Islamic education subjects must have 
creativity to support the implementation of the learning process in the classroom by using various literatures and materials related to Islamic education lessons. In relation to the above, this study focuses on studying the interest of reading the teachers of Islamic high school education subjects in high schools in Bogor and various religious literature choices that are read in order to support the learning process of Islamic education in the classroom. There are several things behind the selection of Bogor city as the target of research, the first city of Bogor is geographically closer to the central government so that automatically any information will be more quickly obtained and accessed. In addition, the city of Bogor also as one of the city supporters of the capital. Second, the dynamics of religious life in the city of Bogor is very diverse and dynamic. Of course, this impact on the knowledge of religion owned by the citizens of Bogor city will be very diverse and third, one of the teachers of Islamic High School Education in the city of Bogor became a model teacher for high school / MA Bogor. Of course, one's assessment of being a model teacher is influenced by several factors such as the ability of a teacher in developing the insight of his scientific knowledge with a lot of learning and reading.

This study aims to obtain complete information on reading interest and the variety of religious literature used by teachers of Islamic high school subjects in high school level in the city of Bogor as input to the Directorate of Islamic Education at the Directorate General of Islamic Education Ministry of Religious Affairs in In providing quality literature to improve the quality of competence and professionalism of teachers of Islamic education subjects. This creates an inclusive development of religious and nationalism.

Improving the quality of teachers' knowledge through literacy reading is important, but this has not received attention. In fact, the importance of teachers as a source of learning deserves more attention to increase the capacity of knowledge, especially for teachers of Islamic Education who have a big challenge related to socio-religious issues in this modern period. However, information on religious literature read by Islamic education teachers is limited, or even not yet available. Though this information is important for efforts to improve the quality of teacher's Islamic education itself.

\section{Research Method}

This research was conducted in Bogor city with the target of Islamic Education teachers in high school in Bogor city, both civil servant and non-Civil 
Servant, certified and uncertified, as many as 38 people. Research conducted in August - September 2016. The method used is qualitative method by using questionnaire as supporting data. The steps taken are in the form of interviews; Indepth interviews of researchers do to some teachers to examine the issues of reading interest and the selection of literature and to dig up information about the literature that is read by asking the variety of contents, or the field of study of the literature that is read in various formats or forms, both of which The nature of reference books, textbooks and enrichment books.

\section{The Significance of Reading Religious Literature According to Teachers Islamic Education at SMA in Bogor City}

This study aims to reveal more deeply about the interest of reading the teachers of Islamic education high school in the city of Bogor. To obtain information and data, the discussion focused on several things, including;

First, how important it is to read the religious literature of the Islamic education teachers; Both the purpose and the benefits of reading religious literature and the three attempts of Islamic education teachers to read and obtain religious literature. First, the importance of reading religious literature among teachers of Islamic education of SMA (senior High School) in Bogor City.This first discussion illustrates how important reading religious literature according to high school Islamic education teachers in the city of Bogor. Based on the results of the research, from 36 high school of Islamic education teachers, as many as 34 high school Islamic education teachers in Bogor city said that reading religious literature is very important, only 2 people said that reading religious literature is important

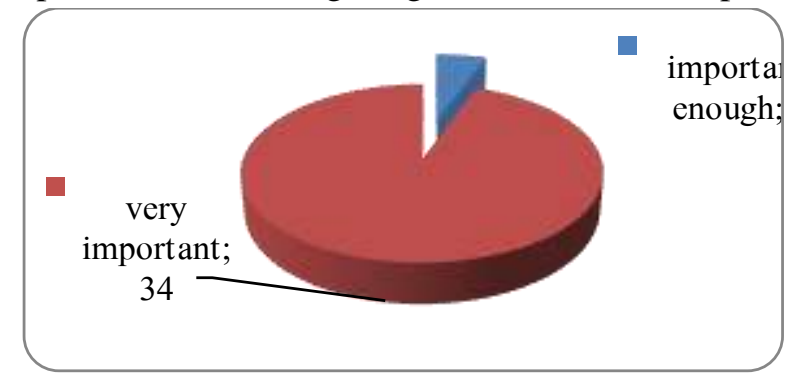

This shows that reading religious literature for teacher of Islamic education in Senior High School is a very important part of everyday life. Especially for the teacher who teaches about Islam, of course, studying religion becomes an inseparable part of their daily life. There are 2 teachers of Islamic education said that it is quite important. This is indicated by the data which shows on how many 
books on Islam have been read in the last six months. The results obtained are 24 high school Islamic education teachers who read books on Islam less than 10 book titles in the last six months; 8 teachers who read 10 - 50 titles about Islam and only 4 teachers who do not read books about Islam in the last six months. This result is quite surprising, especially against 4 high school Islamic education teachers who are not at all reading books about Islam. Though they are teachers who teach and give material about Islam for their students, but do not read books related to Islam.

The results are in accordance with the interest of high school Islamic education teachers on reading religious books, with the following results: as many as 30 teachers of high school Islamic education say very interested in reading religious books, 5 high school Islamic education teachers said enough interested in reading religious books and 1 high school Islamic education teacher who said that he had little interest in reading religious books. There are differences from the above data with previous data, where 34 Islamic education teachers say that reading religious literature is very important, but 30 high school Islamic education teachers are very interested in reading religious books. 1 teacher from 34 teachers said little interest in reading religious books and 3 people said quite interested in reading religious books. 2 high school Islamic education teachers who previously said reading religious literature were important also said the same thing that they were quite interested in reading religious books. After seeing how important it is to read religious literature, other information about where the high school Islamic education teachers add to their religious knowledge. Based on the results obtained, the teachers of Islamic education of SMA (Senior High School) have different ways to increase their religious knowledge. The table shows the variety of how to understand Islamic knowledge is as follows; Religious Knowledge, Source and Amount of Person

\section{Religious Knowledge Sources Amount}

Amount (person)

Reading books or religious literature from magazines, bulletins, religious journals.

Participating in study groups in the environment / office / place of business, reading religious books or literature from magazines, newsletters, religious journals), watching / listening to religious broadcasts on television / radio and through social media (BBM / Whatsapp / Facebook / Line / Twitter )

Watch / listen to religious broadcasts on television / radio 10 8

8




\begin{tabular}{|l|c|}
\hline $\begin{array}{l}\text { Attending recitation groups in the neighborhood / office / place of } \\
\text { business and reading religious books or literature from magazines, } \\
\text { bulletins, religious journals. }\end{array}$ & 2 \\
\hline $\begin{array}{l}\text { Attending study groups in the environment / office / place of business, } \\
\text { reading books or religious literature (magazines, newsletters, } \\
\text { religious journals) as well as through social media (BBM / Whatsapp } \\
\text { / Line / Facebook / Twitter) }\end{array}$ & 2 \\
\hline $\begin{array}{l}\text { Reading religious books or literature from magazines, newsletters, } \\
\text { religious journals and through social media (BBM / Whatsapp / Line }\end{array}$ & 2 \\
/ Facebook / Twitter) 2
\end{tabular}

The above data shows the results of 36 high school Islamic education teachers, there are about 32 teachers \{ Islamic education of SMA (Senior High School) who still use religious books or religious literature in increasing their 
religious knowledge, only 4 teachers who do not use religious books or literature Religion, 3 teachers who increase their religious knowledge through watching / listening to religious broadcasts on television / radio and 1 teacher who increase their religious knowledge through social media (BBM / Whatsapp / Line / Facebook / Twitter).

Besides through religious books or religious literature, the study group either in the environment / office / business place is still the teacher's choice in increasing their knowledge as many as 17 teachers. The choice of watching / listening to religious broadcasts on television / radio became a source of religious knowledge of teachers as many as 12 teachers. Only 1 teacher uses social media (BBM / Whatsapp / Line / Facebook / Twitter) as a means to increase their religious knowledge. Of course, even though only one person, this raises the question, why a religious teacher uses only social media means in increasing his religious knowledge. Whether religious books or religious literature, existing study groups and religious broadcasts on television / radio are not worthy of being a source of religious knowledge.

Secondly, the purpose of reading religious literature. The next discussion is the goal of high school Islamic education teachers to read from religious literature. The following results are obtained; A total of 14 teachers said that the purpose and benefits of reading religious literature was to add insight; 13 teachers who said to add insight and teaching materials; 5 teachers who say for teaching materials; 2 teachers who say for da'wah material; Only 1 teacher said that in addition to to add insight and teaching materials as well as writing materials, and nd only 1 teacher did not say anything.

When viewed from these results, indicating that the goal of reading the teachers Islamic education of SMA (Senior High School) in Bogor city is very varied. The very dominant goal of teachers in reading religious literature is for academic - pragmatic. Academic is intended here as teaching materials, while the purpose of pragmatic where the purpose is used for writing materials, both in the form of books / teaching materials and scientific articles of course.

Nevertheless, there is also the goal of Islamic education teachers reading religious literature aiming theologically for preaching. When viewed from the profile of 2 teachers is very possible, considering the two teachers are actively involved in the management of a particular religious organization. So that the religious literature he read aims as an ingredient in proselytizing in society. While the rest is more pragmatic-academic. 
Third, the efforts of Islamic education teachers to read and obtain religious literature. To find out what attempts by Islamic education teachers to read and obtain religious literature, first look at how Islamic education teachers acquire Islamic literature; Second what is the budget set aside from income to buy the literature in one month; Third how many high school Islamic education teachers read books about Islam in the last six months; Four Frequencies to Bookstore in the last year; The five Frequencies to the Library in the last year.

\section{How to get books about Islam}

To see how the knowledge of high school Islamic education teachers on the importance of reading religious literature, the basic thing to know is how the high school Islamic education teachers obtain Islamic books.

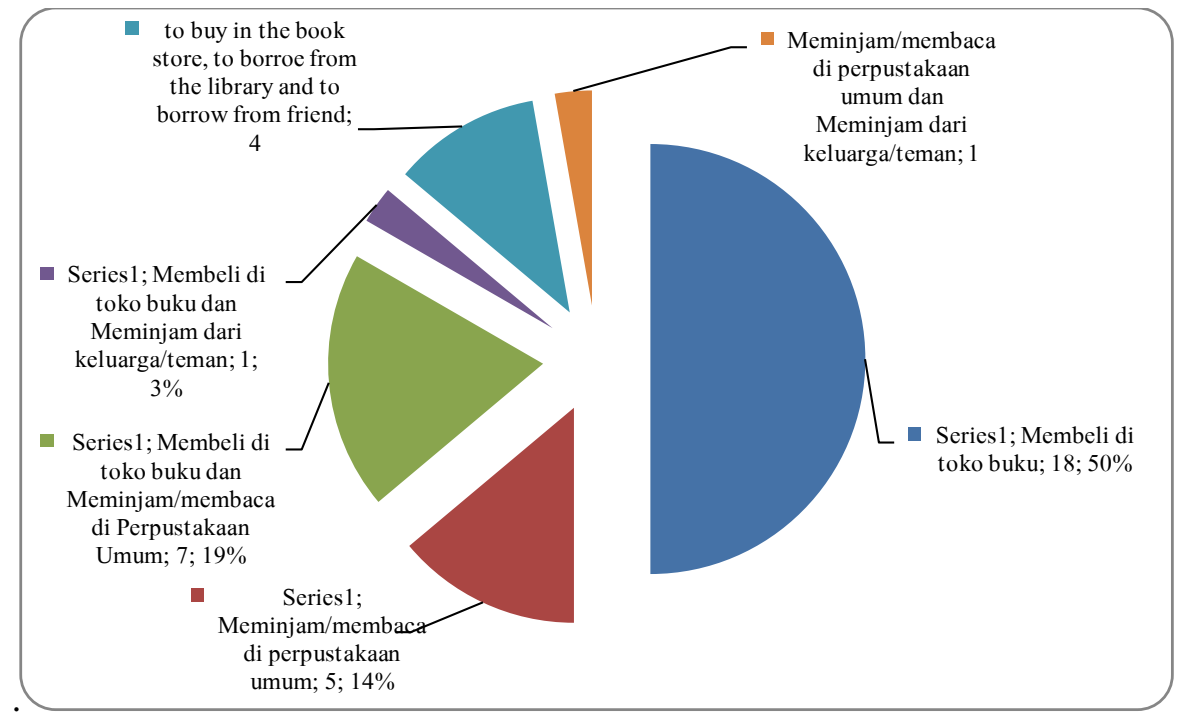

The data obtained stated that as many as 18 Islamic education teachers obtained books on Islam by buying in bookstores, 7 teachers who besides buying in bookstores also borrowed / read in public libraries, 5 teachers who only obtained Islamic books From borrowing / reading in public libraries, 4 teachers in addition to buying in bookstores and borrowing / reading in the public library also borrow books from family or friends and only 1 teacher who borrowed / read in the public library also borrow books from family or friend.

The above results show encouraging results, where teachers of Islamic education of SMA (Senior High School) in Bogor city has a variety of ways to obtain books about Islam. Whatever efforts and ways that the Islamic education 
teachers do deserve appreciation. In the midst of the many household needs, the teachers still set aside their income by buying Islamic books in bookstores. Borrowing / reading books on Islam in public libraries also shows that these teachers still want to spend their time borrowing and reading Islamic books in public libraries. Borrowing books from family or friends should be appreciated as an attempt to gain knowledge about Islam.

This also shows that the school literacy movement proclaimed by the Ministry of National Education Anis Baswedan, really done by the teachers Islamic education high school in the city of Bogor. Variety of efforts made above must continue to be done in order to become a habit that can be transmitted to other teachers.

\section{Budget to buy Islamic book in one month}

As for seeing the efforts of high school Islamic education teachers to read religious literature is to look at the budget set aside each month to buy religious books. Based on the questionnaire results, obtained the following data:

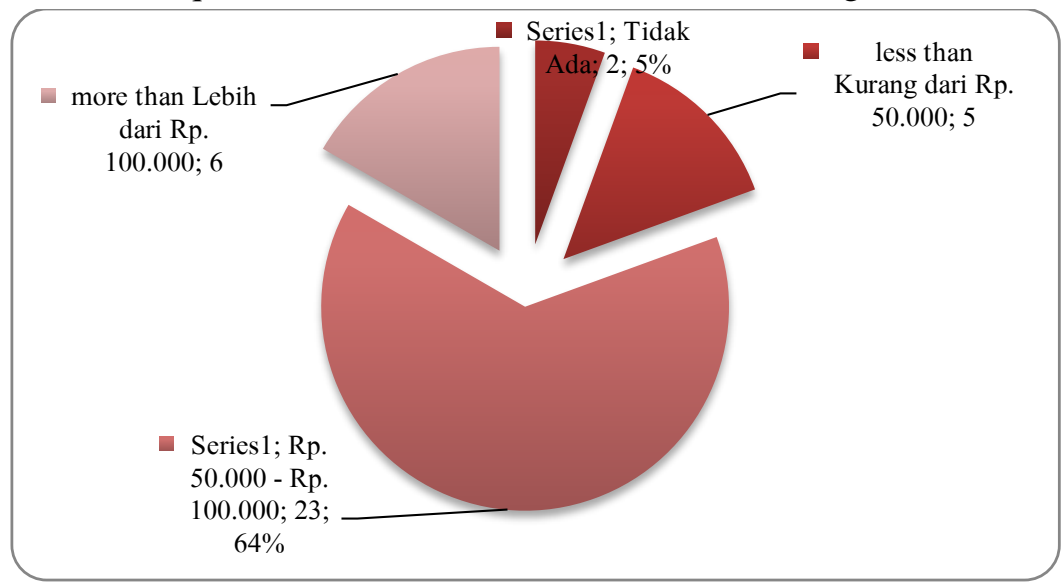

From the table above, obtained information and data that as many as 23 teachers Islamic education high school that set aside their income each month of Rp. 50.000 - Rp. 100,000 to buy Islamic books, 6 teachers who set aside their income each month more than Rp. 100,000 to buy Islamic books, 5 teachers who set aside their income each month is less than Rp. 50.000 to buy Islamic books and only 2 teachers who do not set aside their income each month to buy Islamic books. These results indicate that with the certification program for teachers, the spirit of ISLAMIC EDUCATION high school teachers in Bogor city to enrich the insights and treasures of knowledge, especially about Islam, is shown by setting aside 
income every month to buy Islamic books. It should be appreciated by anyone, either by the Head of School, Education Office and the Ministry of Religious city of Bogor. The spirit of setting aside income to buy a number of books, any book, should continue to be inflated by all parties.

\section{How many reading books about Islam in the last six months}

To see the interest of reading of the teachers of Islamic education, there are questions also given to the questionnaire that is in the last six months, how many titles of books about Islam that have been read by teachers Islamic education high school. Based on the questionnaire that has been filled, the following data are obtained: as many as 23 teachers who bought books about Islam less than 10 book titles in the last six months, 8 teachers who bought books about Islam as much as 10 - 50 books in the last six months, 4 Teachers who did not buy books about Islam in the last six months and only one teacher who bought more than 50 Islamic books.

When looking at the results of the table above, it shows that the level of care and attention of high school teachers Islamic education in Bogor is high enough in having and buying books about Islam. This is an exciting thing for the world of education, especially teachers of Islamic education, who are very concerned with knowledge about Islam. This is a valuable capital for teachers of Islamic education in high school to deliver Islamic materials for students in school.

\section{Frequency to Bookstore in the last year}

To see how much attention and interest of teachers Islamic education SMA Bogor city in relation to the interest of reading books. The highlight is how often the high school Islamic education teachers go to bookstores in the last year. Based on the available data, the following results are obtained; There are only 8 people who almost every month go to the bookstore, although to the bookstore is not always synonymous with buying a book, at least it shows a strong desire from the 8 people to see the books published every month and add Their scientific knowledge of course. Only 2 people go to "once" bookstores over the past year.

\section{Frequency to Library in the last year}

In addition, another point of concern is how often the high school Islamic education teachers visited the library in the past year. From the available data, the following results were obtained: 10 teachers who almost visited each month to the Library, 23 people who visited several times, 2 visiting teachers and 1 teacher who had not visited the Library in the last year.

The presence of teacher of Islamic education in Senior high school who has never visited the library in the last year shows that this attitude is unexpected from 
an educator. As an educator, teacher should spend his time in the midst of busy teaching in the classroom, to visit the library. There are many things that cause the teacher to be bothered to go to the library such as the library in the school does not exist, and it can also be due to the lack of books in the library, or it could be because the books in the library is not so appealing to the teacher.

Of course this should be explored more deeply, what caused the teacher never visited the library. When viewed from the variety of enrichment literature that teachers use in teaching Islamic education at school, that teacher uses only 3 enrichment books only. Of course this becomes a separate record for the school to create a program for teachers to return to the library as a school literacy program that has been proclaimed by the Ministry of National Education.

The same thing is done by 2 high school Islamic education teachers, they only once a year visit and visit the library. This is very apprehensive for the world of education. A teacher who has to be a role model for his students gives an unfavorable example. There should be a movement for teachers, especially teachers of Islamic education in high school, to return to libraries in every school. Libraries should be the place where teachers seek knowledge. Lack of reference in the library can be done by requesting books to several agencies / government agencies such as the National Library of Indonesia which provides a diverse collection of books that are distributed for free.

\section{Various Literature of Teacher of Islamic Education at The SMA (SENIOR HIGH SCHOOL) in Bogor City}

Based on the results of a questionnaire that has been filled by teachers of Islamic education SMA Bogor City, obtained a description of 34 teachers of Islamic education SMA Bogor city, using materials or enrichment literature in teaching of Islamic education in each school. While 2 other high school Islamic education teachers did not use the enrichment materials or literature. They only use Islamic education packages of books published by MONE and a number of publishers. According to their information that the existing Islamic education package books are sufficiently representative in conveying and explaining the Islamic education materials so that no other ingredients are needed as the enrichment in teaching Islamic education at school. The Islamic education books used are published by several publishers, including: Ganesha, Grafindo and Erlangga. The variety of religious literature is based on the material in Islamic education lessons, as follows:

Intizar, Volume 24, Nomor 1, 2018 


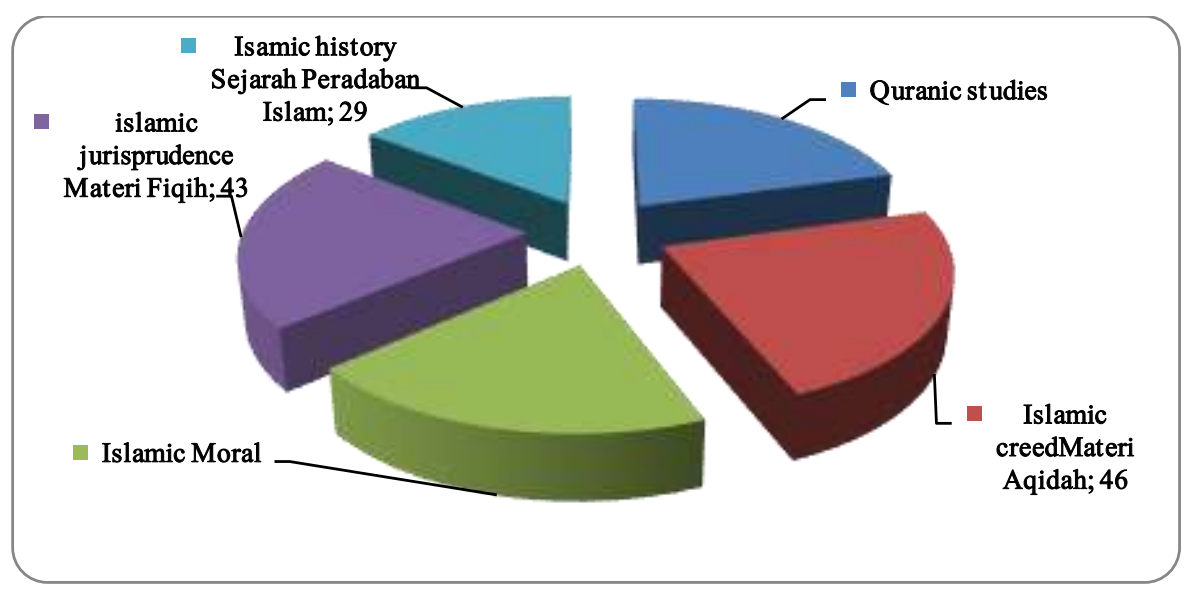

Based on the above table, obtained about 198 enrichment literature which is used as reference of Islamic education high school teachers in Bogor city in teaching subjects of Islamic Religious Education. To the enrichment literature is divided into several materials that are adapted to the existing material in the subjects of Islamic Religious Education, namely; material of al-Qur'an, Aqidah material, Akhlak material, Fiqh material and material of History of Islamic Civilization, with result as follows:

\section{Al-Qur'an Materials}

For the material of the Qur'an, there are 41 titles of books used as material or literature of teachers of Islamic education. In relation to reading interest in teaching enrichment of Islamic education in schools, high school Islamic education teachers in Bogor City mostly use literature in the form of Qur'anic commentary and translations published by the Ministry of Religious Affairs (formerly Ministry of Religion) of 8 persons; Jalalayn's commentary by Jalaluddin Asy-Suyuthi as many as 6 people; Misbah interpretation by Quraish Shihab and Tafsir al-Maraghy each of 4 persons; Ibn Kathir's commentary and Thematic Encyclopedia The verses of Al-Qur'an and Hadith by Ahmad Muhammad Yusuf each of 3 persons; Tafsir alAzhar by Hamka, Tafsir Introduction to the Study of Al-Qur'an Sciences by Shaykh Manna al-Qaththan, al-Hakam's interpretation by the word and Tafsir Fi Dzhilalil Qur'an by Sayyid Qutb each of 2 people. 
Zulkarnain Yani

The Literature of Teacher of Islamic Education at the Senior High School in Bogor City

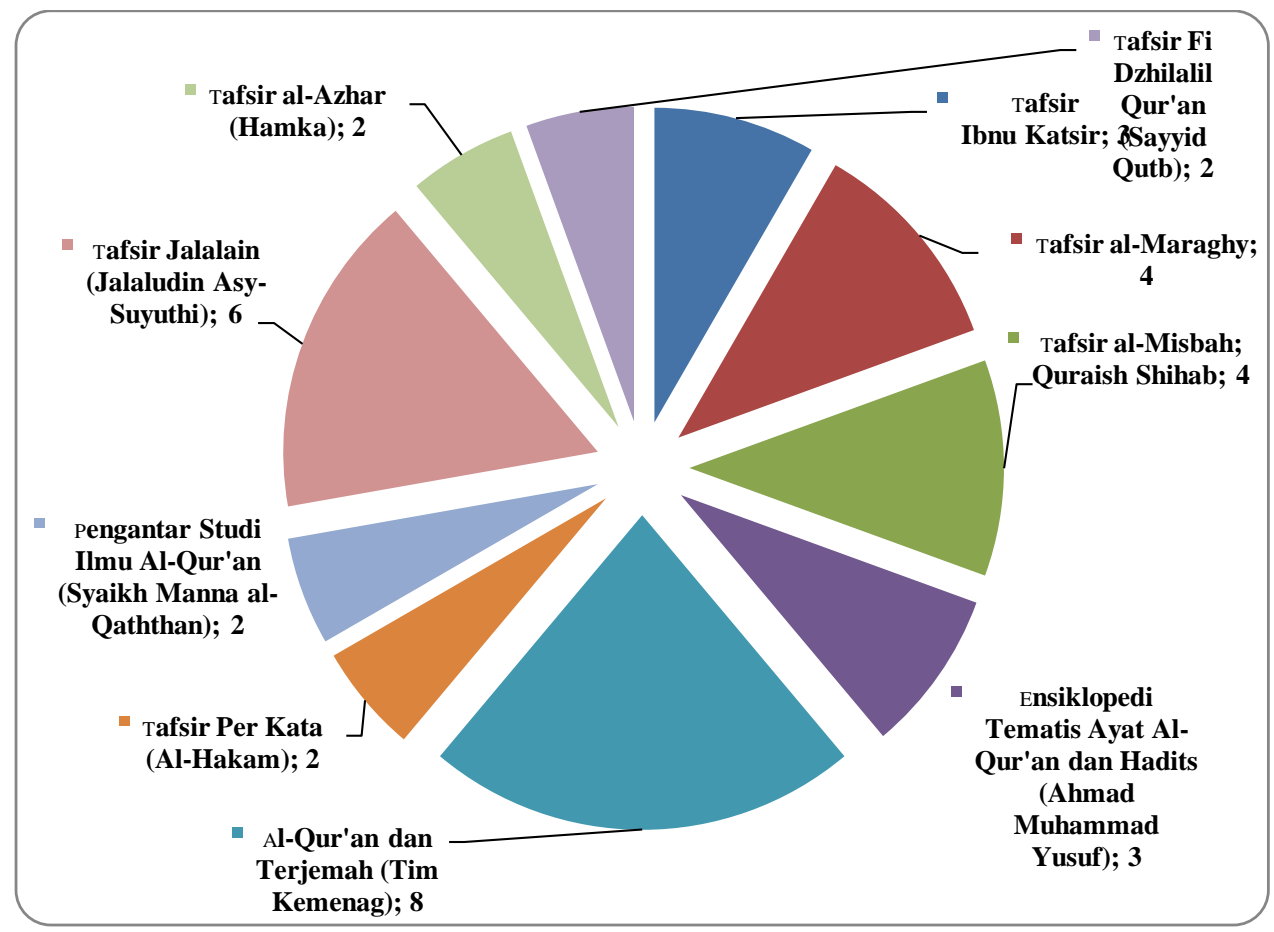

Based on these data, the teachers of Islamic education of SMA (senior High School) in Bogor City use more books that are very familiar we read everyday. Like the Qur'an and its translations printed by the Ministry of Religion, Misbah interpretation by Quraish Shihab, Jalalayn's commentary and other commentaries. Book of Qur'anic interpretation is more widely used, this is because the material of the Qur'an in Islamic education books that are taught many related verses of the Qur'an start from understanding and explaining the meaning of the contents of the letter. The title of the book or other literature used by teachers Islamic education of SMA (Senior High School) in Bogor city as follows: Mu'jizat Al-Qur'an by Quraish Shihab (Yaizun); Mu'jizat Al-Qur'an Sunnah by Mustofa Al-Jami deb (Gema Insani Press); The Encyclopedia of Al-Qur'an Knowledge and Hadith by Tim Baitul Kilmah (Kamil Pustaka); Tafsir Thematic Qur'an by Lajnah Pentashihan Mushaf alQur'an (Kamil Pustaka); Thematic Encyclopedia Ayat Al-Qur'an by the Writer Team (New Votes Van Hoeve); Tafsir Imam Syafi'i by Shaykh Ahmad Musthafa al-Farran Translator; Fedrian Hasmand, Fuad S.N., Ghafur S., Arya N.A; Ibn Kathir's interpretation of al-Qur'an al-'Alim (Makkah); Tafsir al-Khazin by Imam Ala'uddin Ali ibn Muhammad ibn Ibrohim al-Baghdadi (Dar al-Fikr); Introduction 
to the Study of the Qur'an by Muhammad 'Aly Ash-Shabuni (Al-Ma'arif); Asbabun Nuzul (Diponegoro); The Qur'an of the Interpreter Per Word (The Great Voice); Syaamil Al-Qur'an; Tafsir Nurul Qur'an The Work of Allamah Kamil Faqih Imani (Al-Huda); The science of Tajwid works (M. Mas'ud); Heart Lantern by Quraish Shihab; The Nature of God's character by Ibn 'Arabi; Al-Qur'an and Secret Numbers by Abu Zahra an-Najdi; Tafsir an-Nur; Riyadhus Shalihin by Imam Nawawi; Tafsir Al-Qur'an Per Kata by Ahmad Hatta; Tafseer of Tafsir by Ahmad Tafsir; Tafsir Ibn Abbas; Hadith Arba'in Nawawy; Al-Qur'an Ku (Lautan Lestari); Practical and Comprehensive Tajwid by Ahmad Soeharto; The Qur'an and the Translation (YPPQ - Al Huda); Introduction to the Science of Tafsir by Rifat Syauqi Hawawi; Knowledge Library of the Qur'an Volume 1-7 by M. As-Sayid Yusuf and Ahmad Durrah; Ulum al-Qur'an by Muchtar Adam (Makrifat)

\section{Aqidah Material}

Variety of literature that made material in the material Aqidah as many as 47 books that are very varied. Likewise with the interest in reading in the enrichment of teaching ISLAMIC EDUCATION in schools, there are 5 titles of books most widely used as learning materials, namely Aqidah Islam book by Sayyid Sabiq and Basic Principles of Islam According to Al-Qur'an and As-Sunnah Yang Shahih by Yazid Abdul Qadir Jawas published by Pustaka at-Taqwa. The other book is Khutbah Jumat Volume 1 by Zainal Abidin, Ihya 'Ulumuddin a translation of Imam al-Ghazaly and Riyadhus Shalihin, a translation by Salim Bahreisy.

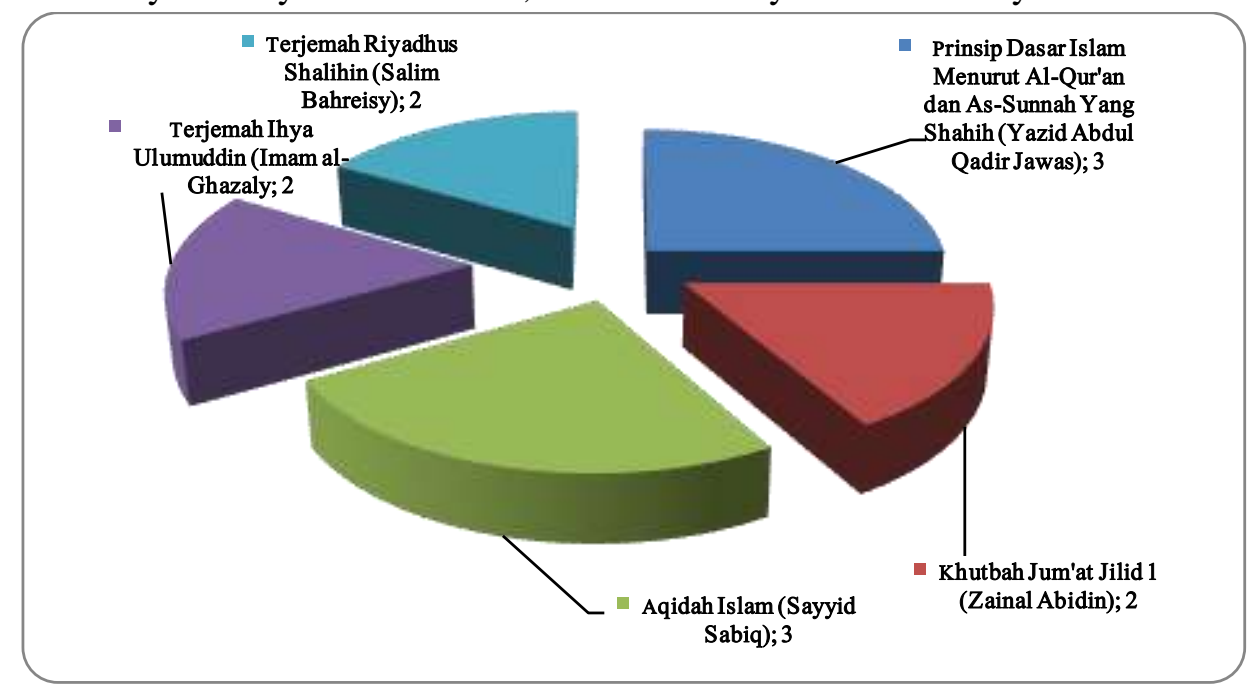

Intizar, Volume 24, Nomor 1, 2018 
As for other religious literature which is also a reference for teachers in delivering the material relating to aqidah, as follows; Fitnah Akhir Jaman by Muhammad bin A.W Al-Aqil; The Smart Book of Eternal Life by Imam AlQurtuby; Science Kalam by Taib Tahir Abdul Mu'im; Tauhid Fire by Habiburrahman El-Shirazy; Islam viewed from various aspects of Harun Nasution's work; Al-Islam by Sa'id Hawwa; Asmaul Husna; Perspective of Al-Ghazaly; Those who are curse of angels by Shaykh Fadhl are divine; Know God by Bey Arifin; Renewal in Islam by Harun Nasution; After Life's Life Bey Arifin; The Pattern of the Living Man's Life by Sayyid Sabiq; Do not ever neglect your Prayer by Hasan Zakaria; Revealing Divine Greatness by Yusuf bin Ibrahim As-Saajir; 40 Principles of Religion by Imam al-Ghazaly; Aqeedah Islam by Muhammad Chirzin; Aqeedah Akhlak by M. Ali Hasan; Quantum Ikhlas by Erbe Sentani; The Touch of Faith The Daughters of Rasulullah by Isnaeni Fuadi; Return to Allah by Abu Dzar AlQalamuni; Syu'ab Al-Iman by Imam Baihaqi; Riyadhush Shalihin by Shaykh Abu Usamah Salim bin Ied al-Hilali; Islamic Mathematics by Fahmi Basya; Translated Ihya 'Ulumuddin by Imam al-Ghazaly; Halal Haram in Islam by Yusuf Qardhawy; Aqidah Smart Books; Practical Guide Sunah Wal Jama'ah In accordance with the Understanding of the Salaf; The Risen Tauhid by Muhammad Abduh; Islam As Aqidah \& Syari'ah by Sheikh Mahmoud Syaltut; Aqeedah Akhlak Volume I by Muhammad Abdul Aziz; 40 Religious Issues Sirajuddin Abbas; Majmu'ah al-Rasail by Hasan al-Banna; Manhaj Aqidah Imam Syafi'i by Muhammad bin A.W.Al-Aqil; Revealing the Divine Scent; Asmaul Husna in Quraish Shihab's Qur'anic Perspective; Collection of Fatwa by MUI and Translation of Riyadhus Shalihin by Salim Bahreisy.

As for other religious literature which is also a reference for teachers in conveying the material relating to aqidah, as follows; Fitnah Akhir Jaman by Muhammad bin A.W Al-Aqil; The Smart Book of Eternal Life by Imam AlQurtuby; Science Kalam by Taib Tahir Abdul Mu'im; Tauhid Fire by Habiburrahman El-Shirazy; Islam viewed from various aspects of Harun Nasution's work; Al-Islam by Sa'id Hawwa; Asmaul Husna; Perspective of Al-Ghazaly; Those who are curse of angels by Shaykh Fadhl are divine; Know God by Bey Arifin; Renewal in Islam by Harun Nasution; After Life's Life Bey Arifin; The Pattern of the Living Man's Life by Sayyid Sabiq; Do not ever neglect your Prayer by Hasan Zakaria; Revealing Divine Greatness by Yusuf bin Ibrahim As-Saajir; 40 Principles of Religion by Imam al-Ghazaly; Aqeedah Islam by Muhammad Chirzin; Aqeedah Akhlak by M. Ali Hasan; Quantum Ikhlas by Erbe Sentani; The Touch of Faith The 
Daughters of Rasulullah by Isnaeni Fuadi; Return to Allah by Abu Dzar AlQalamuni; Syu'ab Al-Iman by Imam Baihaqi; Riyadhush Shalihin by Shaykh Abu Usamah Salim bin Ied al-Hilali; Islamic Mathematics by Fahmi Basya; Translated Ihya 'Ulumuddin by Imam al-Ghazaly; Halal Haram in Islam by Yusuf Qardhawy; Aqidah Smart Books; Practical Guide Sunah Wal Jama'ah In accordance with the Understanding of the Salaf; The Risen Tauhid by Muhammad Abduh; Islam As Aqidah \& Syari'ah by Sheikh Mahmoud Syaltut; Aqeedah Akhlak Volume I by Muhammad Abdul Aziz; 40 Religious Issues Sirajuddin Abbas; Majmu'ah al-Rasail by Hasan al-Banna; Manhaj Aqidah Imam Syafi'i by Muhammad bin A.W.Al-Aqil; Revealing the Divine Scent; Asmaul Husna in Quraish Shihab's Qur'anic Perspective; Collection of Fatwa by MUI and Translation of Riyadhus Shalihin by Salim Bahreisy

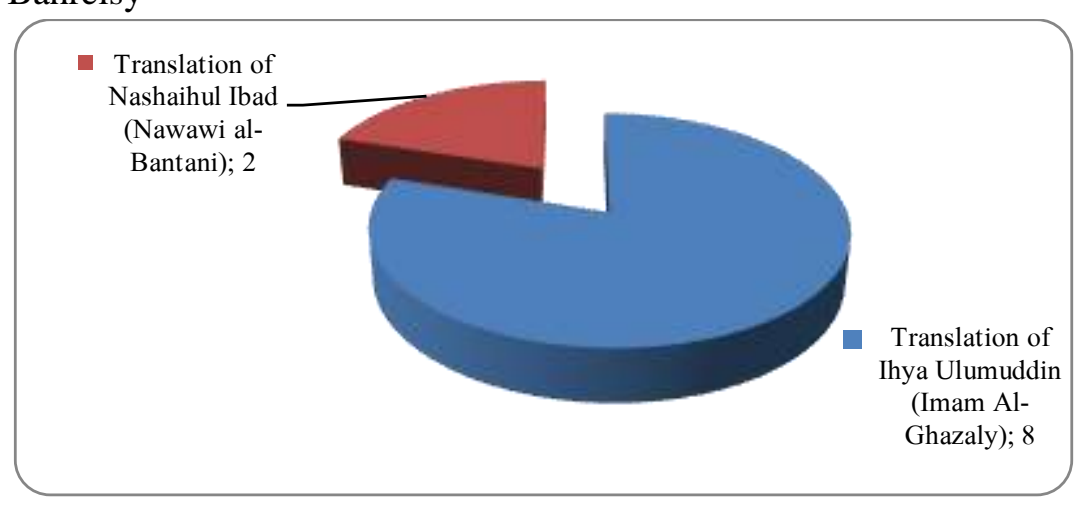

Ihya 'Ulum al-Din's translation book Imam al-Ghazaly became the primary source book among high school of Islamic education teachers in delivering and teaching matters pertaining to morals. As we all know, books are very popular and can be found in many bookstores. What is interesting here is the existence of a book by scholars of the archipelago the so called Nasaih al-'Ibad, Translation by Shaykh Imam Nawawy al-Bantany, which made as a material of Islamic education enrichment of teachers in high school. Ihya 'Ulumuddin book is a very popular book and always used as a reference in every learning and teaching of religion.

As for other books or religious literature used by high school of Islamic teachers as follows; The translation of Riyadhus Shalihin by Salim Bahreisy; Tarbiyah Rasulullah by Najib Khalid; Acts of Moral Acts of Praise by Fuad Kauma \& Nifan; The Exemplary Stories of Abdurrahman Arabi; Minhajul Muslim by Shaykh Abu Bakar Jabar al-Jazairi; Islamic Ethics; Development of Akhlakul 
Karimah by Hamzah Ya'cub; Spiritual Education by Sa'id Hawwa; Minhajul Qashidin by Ibn Qudamah; Rajin Jum'atan But Vain: The Errors of Praying Friday by Husayn ibn Ali ibn Abdurahman Asy-Syaqrawi; Shohih Asbabun Nuzul by AsyShaykh Muqbil bin Hadi; The History of Muhammad's Life by Haekal; The level of Peace and Happiness of the Believers by Hamzah Ya'cub; Tarbiyatun Nisa; Morals of Women; Reflecting on the Prophet's Hade of Hadi Sumarna; 366 Sugiasih's example of the Muslim Child; Jurisprudence by Musthafa al-'Adawy; Actualization of Muslim Morals by Umm Ihsan and Abu Ihsan al-Atsari; Muslim Charity by Oemar Bakry (Mosaic of Sin) by Mutawalli Asy-Sya'rawi, ESQ Power by Ary Ginandjar, World Pleasure Just a Little Than The Hereafter by Abdul Latif Gratitude, Patient and Gratitude Therapy of Imam Al Ghazaly; Adabuddunya wa ad-din by Abil Hasan Ibn Muhammad Habib Alba Skhriwawardi, Halal Haram in Islam by Yusuf Qardhawy, Riyadhus Shalihin by Imam Nawawi: Encyclopedia of Mu'jizat Al-Qur'an and Hadith by Hisham Thalbah; Translation of Hadith About Person and Character The Messenger of Allah (peace and blessings of Allaah be upon him), the Messenger of Allaah (peace be upon him), the Messenger of Allaah (peace be upon him), the Messenger of Allah (peace and blessings of Allaah be upon him), the Messenger of Allah (peace and blessings of Allaah be upon him) Amanah, Fathonah, Tabligh by Muhammad Areya Laranta, Shaping the More Islami Private by Ridwan Asy-Syirbany; Muhammad Saw's Encyclopedia of Leadership \& Management by M. Syafi'i Antonio; 80 Disgraceful \& Praised Nature by Mahyudin Ibrahim; and Aqidah Islam by Sayyid Sabiq.

\section{Fiqih Material}

The variety of religious literature that is used as a reference by teachers Islamic education of SMA (Senior High School) in Bogor city is very varied. There are 43 literatures used by high school Islamic education teachers as their enrichment materials in teaching fiqih material in school. The most favored literature by these teachers is Fiqh Sunnah by Sayyid Sabiq as many as 16 teachers; Islamic Fiqh by Sulaiman Rashid as many as 7 people; The translation of Fathul Mu'in by Aly As'ad Zainuddin bin Abdul Aziz and Bulughul Maram's translation by Mochammad Machfuddin Aladip of 3 persons; Masail Fiqhiyah, Translation Durratun Nashihin by Abu AF Ramadlan and Fikih Wanita each of 2 people. 


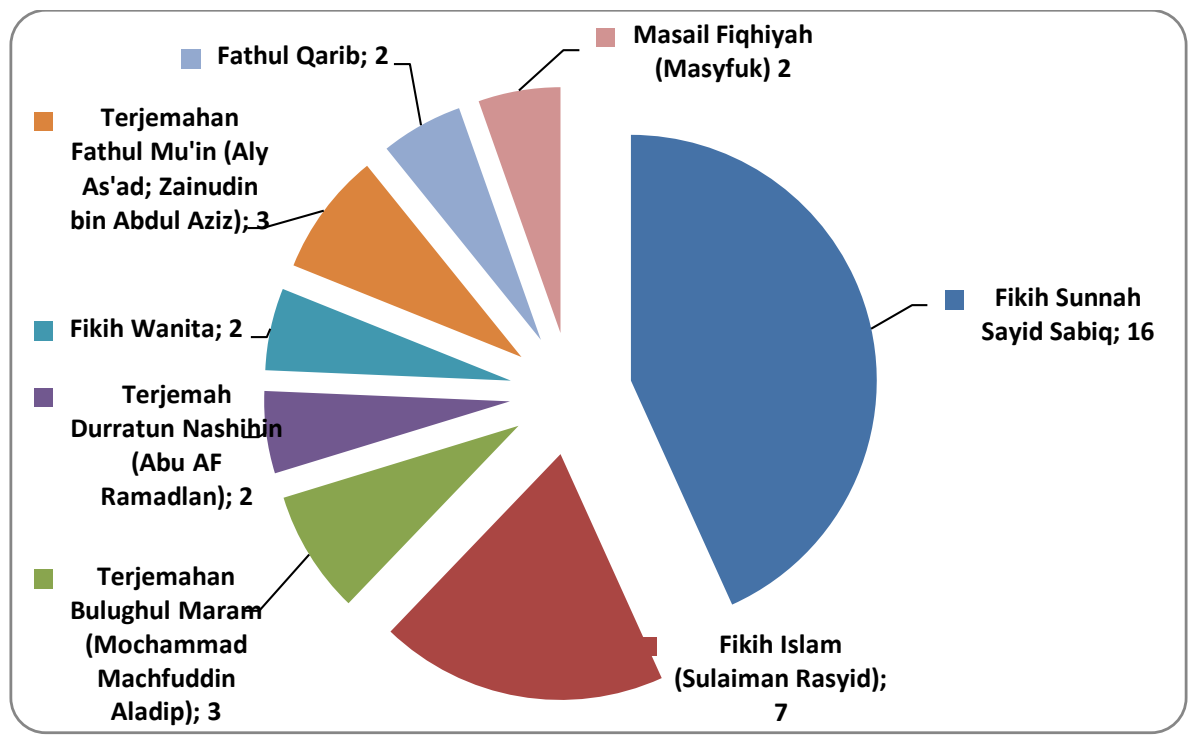

There is something interesting when looking at interest in reading the high school Islamic education teachers who are more likely to use the book translation Fiqih Sunnah by Sayyid Sabiq. The translation book of Jurisprudence is one of the most common books of fiqh in the bookstores. So it is not difficult for teachers to find and buy the book. In addition, the book has long been circulating in the community and experienced some reprints due to the many interests of the community, not just religious teachers, to the book of Jurisprudence. Similarly, the book of Islamic Ficih by Sulaiman Rasjid. The book of Jurisprudence Sulaiman Rasjid itself (= better known as such a mention) has been around and most popular since the 1980s, widely used by all circles and made reference in worship and worship. In some ta'lim assemblies too, the teachers or preachers still use the Ficih Sulaiman Rasjid. Even the book of Jurisprudence became the most read book and made reference for the candidate hajj officer at the time of following selection of candidate hajj officer. Interestingly here, there are books of jurisprudence that we often encounter in boarding schools, such as the book of fath al-Qarib, Durrah alNasihin, Fath al-Mu'in and Bulughul Maram which became the choice of high school Islamic education teachers in delivering the material Fiqih. With the high number of Islamic education high school teachers on the top 2 books, namely Fiqih Sunnah by Sayyid Sabiq and Fikih Islam by Sulaiman Rasjid shows that teachers of Islamic education of SMA ( Senior High School) in Bogor prefer fikh books that 
are popular in society, the 2 books of jurisprudence from content aspect ( Content) can be accepted by any circle, in addition to the material contained in the 2 books is quite simple and easy to understand by anyone.

\section{The Material of History of Islamic Civilization}

As for the material of History of Islamic Civilization, the literature referenced by teachers Islamic education of SMA (Senior High School) in Bogor city as much as 29 books that discuss the issue of the history of Islamic civilization, whether the history of Prophet Muhammad Saw or Sirah Nabawiyah, the history of the Companions of the Prophet, the history of Prophet and Rasul, The history of the great Muslims in the world and the history of Islamic culture.

Of the many books, there are 3 titles of the most referenced and enriched books, namely Muhammad Husein Haikal's History of Muhammad's Life History as much as 3 teachers; History of Islamic Civilization by Badri Yatim and History and Islamic Culture by A. Syalabi each of 2 teachers.

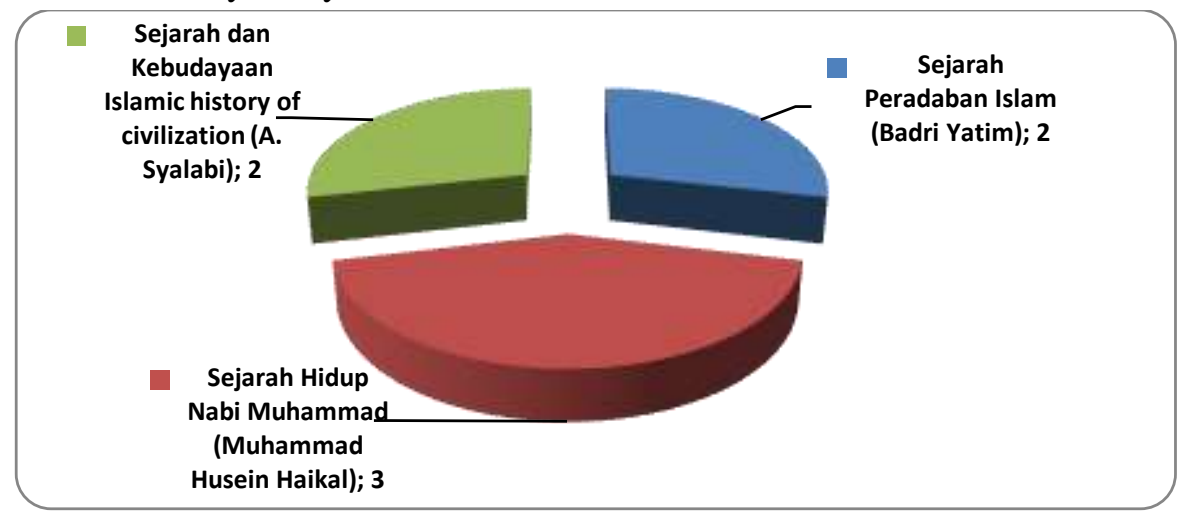

In addition to these two books, the enrichment books for the material of the History of Islamic Civilization, as beriku; Muhammad As A Trader by Afzalurahman; Islam in Southeast Asia by Ahmad Ibrahim et al. Islam and Modernism by Maryam Jamilah; The history of the Prophet Mohammed Saw by Ibn Kathir; History of The Arabic by Philip K. Hitti; Abu Bakar The Ist Khalifa by Misbah Em Majidy; The face of Adian Husaini's Western Civilization; Muhammad Zainal Arifin's Life Fairy; History of Islamic Civilization; The history of the Apostles by Hilmi Ali Syaiban; Hijra in the Qur'an View by Ahzami Samiun Jazuli; Tarikh Tasyriq by Muhammad Zuhri; Sirah Prophet by Syafe'i Antonio; George Jordac's Sound of Justice; The Last Moments of the Life of the Prophet by the work of Firdaus AN; Encircling the New Way of Islam by Fachry Ali and Bakhtiar 
p-ISSN: 1412-1697; e-ISSN: 2477-3816

http://jurnal.radenfatah.ac.id/index.php/intizar

Effendi; Qishashul Anbiya by Hadiyah Salim; Sirah Nabawiyah by Shafiyyurrahman al-Mubarak Fari; Islamic history by Hashbi Ash-Shiddiqi; The story of 25 Prophets and Apostles; Islamic Encyclopedia by Ahmad Fawaid; History and Islamic Culture For Aliyah published by the Ministry of Religious Affairs; The 100 Greatest Muslims of All Time Teguh Pramono's work; Muhammad Syafi'i Antonio's Leadership \& Management Encyclopedia; History of Islamic Culture by Muradi; Anas Ma'ruf's Short History of Islam; And Islamic History from Andalus to Indus by Muhammad Tohir.

From the description above, the result that can be seen is that there are only 29 books or religious literature. It shows that the wealth of religious books or literature teachers of Islamic education at SMA in Bogor city for material of History of Islamic Civilization is still far from the ideal than the literature used for the material of the Qur'an, Aqidah, Akhlak and Fiqih. Of course this is a separate note for high school of Islamic education teachers, where they have to enrich more variety of books or related religious literature on the rich history of Islamic civilization.

\section{Conclusion}

Based on the results of the research that has been obtained and described above, there are some points that can be concluded about the interest in reading and the variety of religious literature in demand. Reading Interest; Regarding the interest of reading the teachers of Islamic education of high school in the city of Bogor is very diverse and varied. Overall, reading interest owned by high school teachers of Islamic education in Bogor city is still very good. This is seen from the urgency of the importance of reading religious literature that shows as many as 34 high school teachers of Islamic education or $94 \%$ who said that it is very important, only 2 teachers or $6 \%$ who say enough important. The results are also supported by 30 high schoolof Islamic education teachers or $83 \%$ who are very interested in reading religious books, 5 teachers or $14 \%$ who are interested enough and only 1 teacher or $3 \%$ are not interested. These results are very encouraging that the teachers of Islamic High School Education (SMA) in the city of Bogor, especially those who have certification, have a high interest in reading.

From the table above we can conclude that the teachers of Islamic education at SMA (Senior High School) in Bogor City further enrich their literature on Aqidah material as much as 46 books or $23 \%$, for the second largest fiqih material of 43 books or $22 \%$, for the material of the Qur'an as many as 41 books or $21 \%$, for the material Akhlaq 39 books or $20 \%$ while the history of Islamic Civilization only 29 
books or 14\%. These results indicate that the teachers of Islamic education at SMA in Bogor city more oriented to the literature containing theological materials. While the literature for the material History of Islamic Civilization is only 29 books only. Of course the results are still far from expectations, given the Islamic History material that is in the book of Islamic education package, both the Education Department and other publishers, the content of the material is still very weak and less once. Like the material of Modern-day Islam (1800 - present). The Islamic figures conveyed in the book material of Islamic Education and Budi Pekerti Education Department published very little. 


\section{Daftar Pustaka}

Abdullah, S. (2016, Agustus 18). Menggalakkan Budaya Membaca Guru Dalam Rangka Pengembangan Keprofesionalan Berkelanjutan. Diambil kembali dari http://www.infodiknas.com/menggalakkan-budaya-membaca-guru-dalamrangka-pengembangan-keprofesionalan-berkelanjutan.html

Apandi, I. (2016, September 15). Guru dan Budaya Literasi. Diambil kembali dari http://www.kompasiana.com/idrisapandi/guru-dan-budayaliterasi_568cf007f77a614115a384e2

Burgess, S. R., Sargent, S., Smith, M., Hill, N., \& Morisson, S. (2011). Teachers' Leisure Reading Habits and Knowledge of Children's Books: Do They Relate to the Teaching Practices of Elementary School Teachers? Reading Improvement, 4.

Clark, C., \& Rumbold, K. (2006). Reading for Pleasure. National Literacy Trust.

Cramer, E. H., \& Blachowichz, C. L. (1980). Teacher as Readers: An Extension of the "Impact of Reading" Survey. Reading Horizons, 20(4).

FAS. (2016, Agustus 18). Minat Baca Rendah, Mayoritas Warga Indonesia Hobi Nonton Televisi. Diambil kembali dari (http://regional.kompas.com/read/2016/04/28/21020061/Minat.Baca.Rendah. Mayoritas.Warga.Indonesia.Hobi.Nonton.Televisi

Huang, H.-C., Tsai, Y.-H., \& Huang, S.-H. (2015). The Relevant Factors in Promoting Reading Activities in Elementary School. International Journal of Evaluation and Research in Education, 4(2).

Khairuddin, Z. (2013). A Study of Student's Reading Interest in a Second Languange. International Education Studies, 6(11).

Kridalaksana, H. (1984). Kamus Linguistik. Jakarta: Gramedia.

Kunandar. (2007). Guru Profesional. Jakarta: Rajawali Press.

Miller, J. W. (n.d.). Retrieved from http: // webcapp .ccsu.edu /? news $=1767 \&$ data)

Munir, S. (2016, Agustus 18). Minat Baca Rendah, Mayoritas Warga Indonesia Hobi Nonton Televisi. Diambil kembali dari http://regional.kompas.com/read/2016/04/28/21020061/Minat.Baca.Rendah. Mayoritas.Warga.Indonesia.Hobi.Nonton.Televisi

Semiawan, C. R. (2008). Belajar dan Pembelajaran Pra Sekolah dan Sekolah Dasar. Jakarta: Ideks.

Sulandari, L. E. (2016, Agustus 19 ). Urgensi Budaya Literasi untuk Membangun Peradaban Suatu Bangsa. Diambil kembali dari 
Zulkarnain Yani

The Literature of Teacher of Islamic Education at the Senior High School in Bogor City

http://www.wartaseni.com/2016/06/urgensi-budaya-literasi-untuk-

membangun-peradaban-suatu-bangsa.html

Trimanto. (2016, Agustus 18). Rendahnya Minat Baca di Kalangan Guru. Diambil

kembali dari http://halopendidikan.com/rendahnya-minat-baca-di-kalanganguru/ 